\title{
PERCEPTION OF RURAL TOURISM AND ITS DEVELOPMENT IN THE MOUNTAIN REGION OF SUCEAVA COUNTY FROM THE PERSPECTIVE OF THE HOST COMMUNITY
}

DOI: https://doi.org/10.18509/AGB.2020.12

UDC: 338.48-6:379.845]:911.373:551.4.035(498)

Vasile Efros, Liliana Daniela Diacon, Cristian Ciubotaru

Ștefan cel Mare University of Suceava, Faculty of History and Geography, Departament of Geography, Romania

corresponding author: diacon_dana@yahoo.com

\author{
submitted: 03.02.2020 \\ accepted: 22.04 .2020 \\ published: 20.08.2020
}

\begin{abstract}
The mountain area of Suceava county presents real opportunities for tourism development, having many unique and well-preserved tourism, valued in terms of age, originality and accessibility, a large number of traditional rural househods and a generous number of accommodation places.

The data of the National Institute of Statistics from 2019 about the capacity of tourist accommodation, places Suceava county on the third place, after Constanța and Braşov counties.

The present study follows the perception of the host community vis-à-vis rural tourism and its development in the mountain region of Suceava county.

The research highlights the role of the county and local authorities in the development of rural tourism and its promotion from the point of view of the host community.

The methodology is based on the survey based on the questionnaire using the gender and age quotas method, respecting the proportional geographical dispersion of the reference population in the mountain region of Suceava county.

It is confirmed the hypothesis that the gap between the aspirations of the population to the development of rural tourism is large, and its diminution requires the preparation of the host population.

In conclusion, following the analysis of the results it is found that the rural population must be trained through courses in order to learn how to capitalize on their existing resources and to become a good host for the potential tourists.
\end{abstract}

Keywords: tourism rural, mountain area, development, the host community.

\section{INTRODUCTION}

Rural tourism is a concept that covers the tourism activity carried out by the local population, based on the local natural and anthropic potential [5]. In the last two decades, in many member countries of the European Union, rural tourism is considered as a future strategy, which can contribute to the economic and social development of local communities, job creation and migration reduction [15]. Given that $87.1 \%$ of Romania's surface is rural and $43.59 \%$ of the country's population lives in the village, rural tourism involves the following aspects: existence of rural areas, conservation of rural functionality, conservation of rural infrastructure, conservation of traditional lifestyle, conservation specifies cultural identity. [10]. The village is approached with a special human significance, identified with the local traditions, the religious holidays much more present in comparison with the urban environment. [1] or offers a mythological tourism potential, in particular its mountain pastoral form [13].

In other words, the village hosts complex activities, promoting tradition, returning to origins, discovering nature and beauty. Rural tourism is one of the solutions for the development of the whole rural area. [6] Its appearance and arrangement within the mountain village offers new sources of income to the population, especially when the area has high potential, high quality human resources and modernized infrastructure that allows access to the mountain region. The path to success is paved by a general development of the rural environment, based on a moderate increase in time and for the benefit of the rural area, because a 
rapid or disorderly development of rural tourism can harm the environment and affect the local population. [6] One aspect that should not be ignored is the preparation of the local population both from a social and professional point of view [12] for the tourist activities in the mountainous areas of Suceava county and through feasible market studies, food production should be organized with adaptation to demand, as well as by tourist motivation. Thus, rural tourism can be included in all tourism activities in the region, as

\section{STUDY AREA}

The mountain region of Suceava county occupies $53 \%$ of the total area of the county and is integrated in the Eastern Carpathian chain. [4] The study area overlaps the mountain region and is composed of 36 mcommunes and includes massive peaks and well as in the context of regional policy. We can say that the Romanian village successfully crossed less favorable periods of history, keeping the purity of its ancient culture largely unaltered. The development of rural tourism is meant to increase the standard of living, stabilize the population, maintain the cultural identity [7], increase the economic power at local and national level [14], while maintaining the ecological balance and the protection of the natural environment. [15]

complexes separated by deep valleys [2],[3] or depressions: the Suhard and Călimani Massifs, the Giumalău - Rarău Massifs, the Bistrița, Stânișoara Mountains, The Feredeu and Mestecăniş peaks.

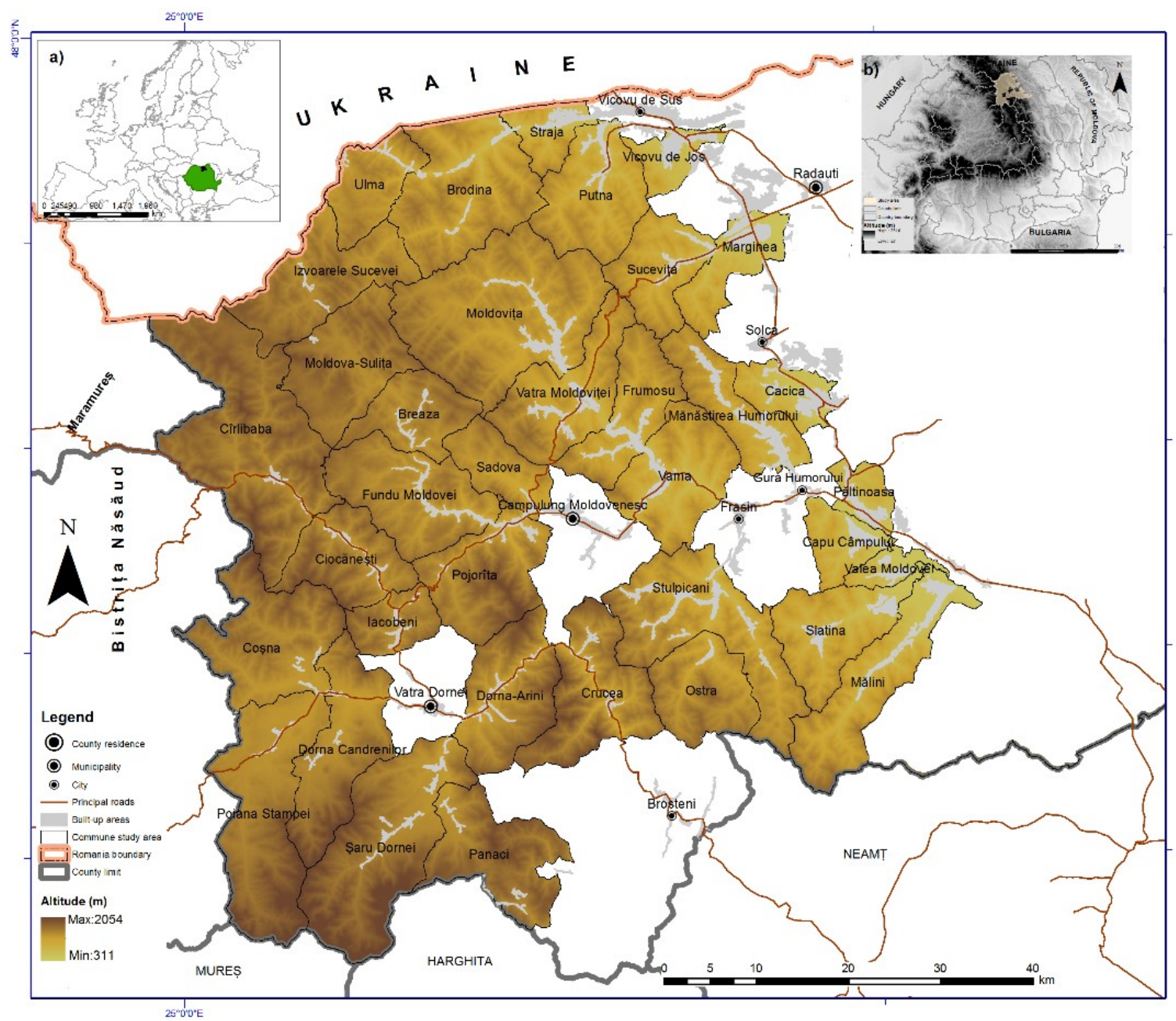

Figure 1. Map of the mountain area in Suceava county.

\section{METHODOLOGY}

The methodology is based on the survey based on the questionnaire using the method of gender and age quotas, respecting the proportional geographical dispersion of the reference population from 36 localities in the mountain region of Suceava county. The survey was anonymous to ensure the highest degree of sincerity of the answers and was conducted between September 1 and November 30, 2019. In view of the representativeness requirements in the literature [8], for the studied area we have constituted a sample of 720 of subjects. The questionnaire 
consisted of 14 relevant questions regarding the perception of the host community on tourism. The first questions concern how the host community perceives the involvement of local and county authorities in promoting and developing rural tourism in the area under study. The following questions refer to the knowledge of the projects, the information mode and the involvement of the host communities in the rural tourism activity. The first question of the questionnaire refers to the role of
Town Hall in the development of tourism in the communes in the mountain area of Suceava county. Do you consider that the Town Hall has been sufficiently involved in the development of tourism in your commune? The host community states in a significant percentage of $63 \%$ that the Town Hall has been involved in the development of rural tourism in the mountain area of Suceava county (figure no. 2).

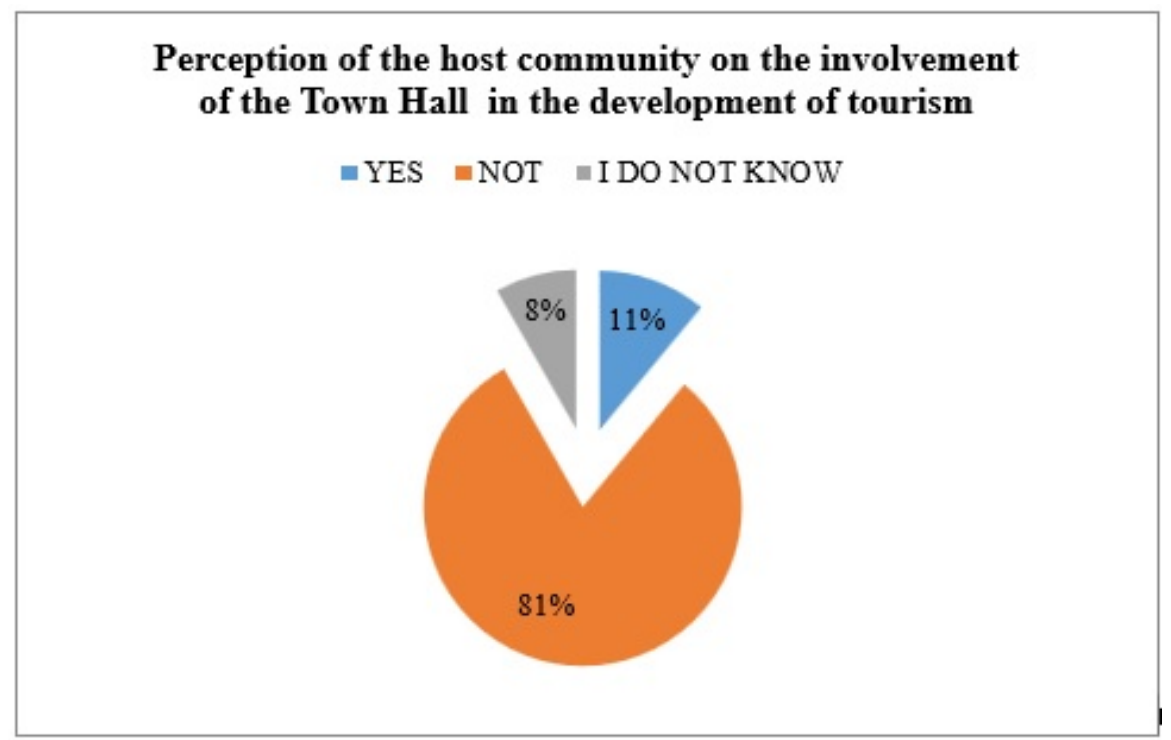

Figure 2. Distribution of answers to question no. 1.

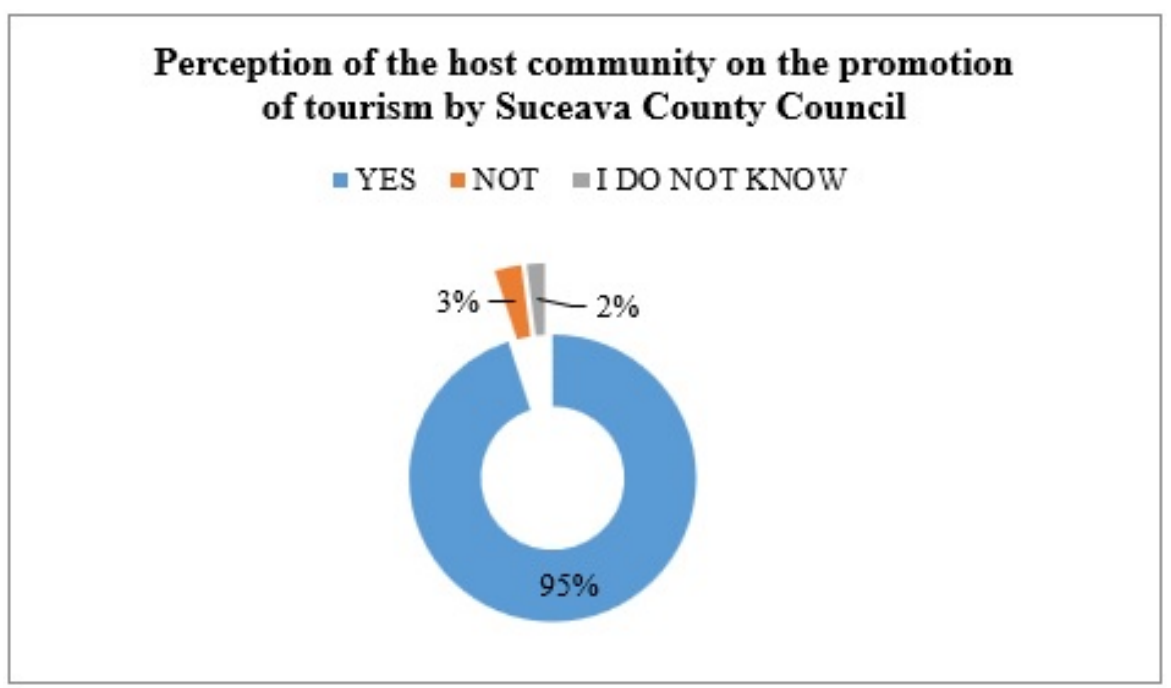

Figure 3. Distribution of answers to question no. 2 .

Another element of interest for our study is the perception of the host community on the involvement of Suceava County Council in the tourism promotion of the county. In this regard, it was found that the citizens are satisfied with the involvement of the county authorities in promoting tourism, most of the respondents answered yes $(95 \%)$ and only $3 \%$ are not satisfied with the way tourism in Suceava is promoted. Do you consider that the Suceava County Council was sufficiently involved in the tourism promotion of Suceava County? The distribution of the answers can be seen in the figure no. 3 Although the citizens have shown confidence in the local and county authorities, it is observed that they still want a greater involvement in attracting European funds in the mountain area of Suceava county. To the question: Do you consider that the Town Hall should attract more European funds for tourism development in your commune. 


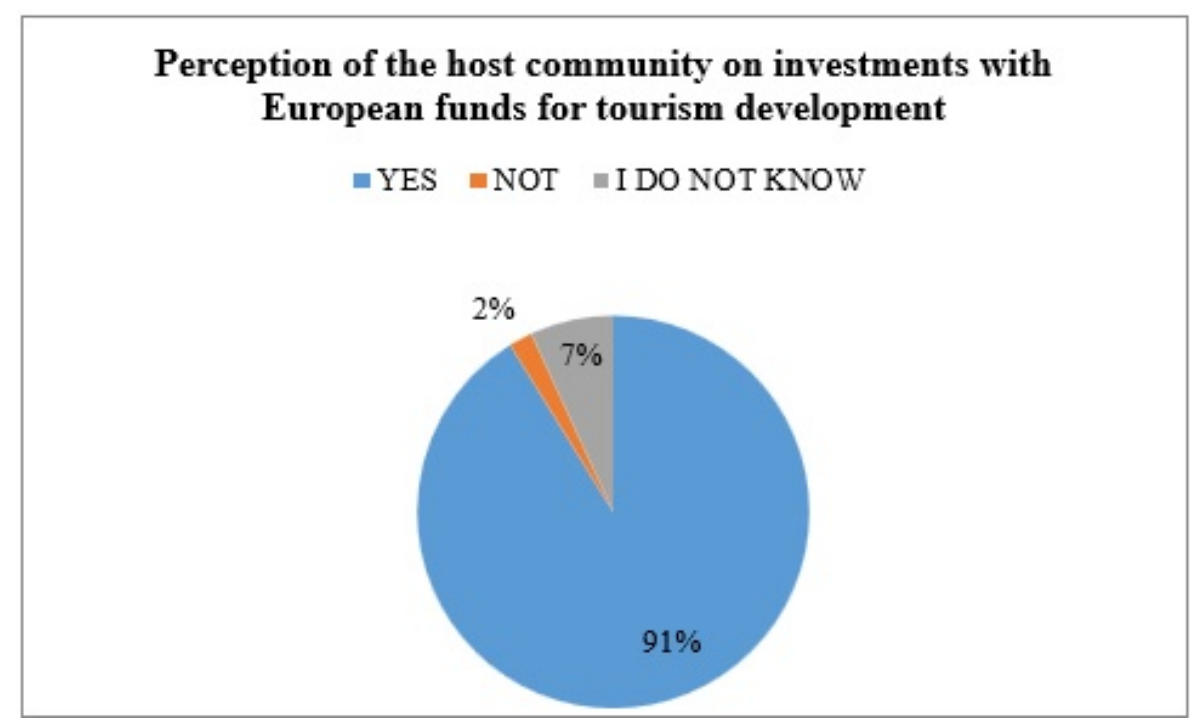

Figure 4. Distribution of answers to question no. 4.

It is observed (figure 4) that most of the respondents are of the opinion that the town halls should attract more funds for tourism development (91\%). It can be deduced that the citizens are aware of the tourism potential of the area taken for study and consider that the investments in the tourist infrastructure, will generate the appearance of several tourist pensions (figure 5), which will lead to an economic growth of the studied area. It should not be ignored that lately the number of tourists has increased in
Suceava county. According to the data provided by the National Institute of Statistics, in 2017 the flow of tourists registered an increase of $12.5 \%$ compared to 2016. Reported at national level it is found that the number of tourist reception structures in Suceava county ranks third, holding $5.6 \%$ of the total number of tourist reception structures, after Braşov county with $12.1 \%$ and Constanta county with $10.6 \%$. [9]

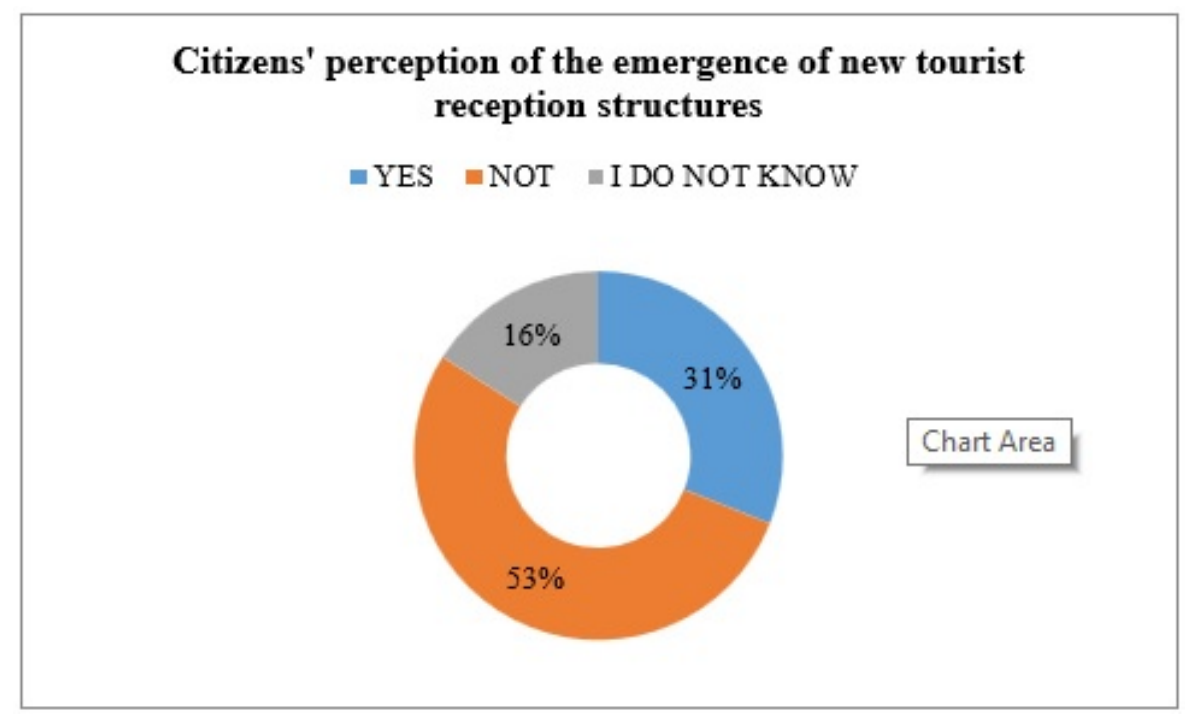

Figure 5. Distribution of answers to question no 5.

As expected, the citizens of the mountain area want more accommodation in the study areas, motivated by the fact that the number of tourists in Suceava county is increasing, according to the data of the National Institute of Statistics. At the same time, citizens believe that the emergence of new reception structures would directly contribute to the creation of new jobs in the area. When asked: Do you consider that the development of tourism in the commune will lead to the creation of new jobs? The answers were $90 \%$ affirmative, only $1 \%$ of those surveyed considered that the development of tourism will not generate new jobs. (Figure 6). 


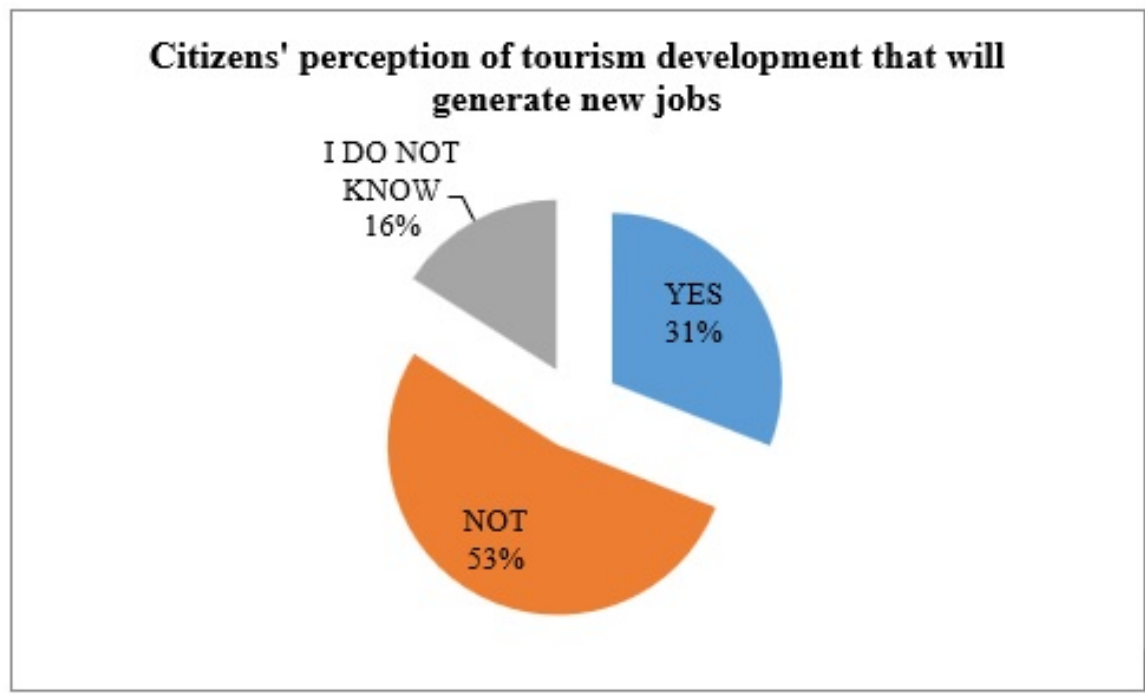

Figure 6. Distribution of answers to question no.6.

Interesting is the opinion of the citizens vis-à-vis how to involve the Town Hall in making tourist markings in the communes in the studied area.
Do you consider that the Town Hall has been sufficiently involved in making tourist markings in your commune?

\section{Citizens' perception of the involvement of local authorities in the execution of tourism indicators}

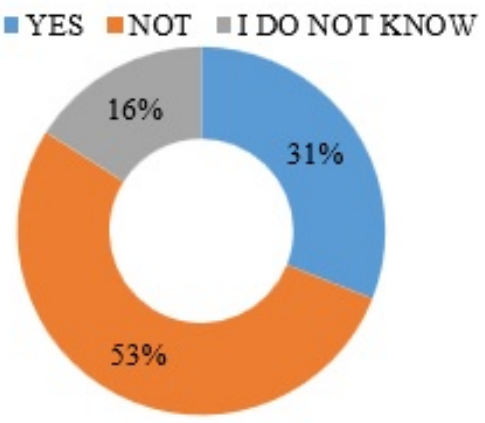

Figure 7. Distribution of answers to question no 7.

It can be observed (figure 7) a dissatisfaction of the citizens on the way in which the local authorities' arrangement of the indicators takes place implicitly of the tourist promotion of the communes, more than half of the respondents were of the opinion that the Town Hall were not sufficiently involved in making the tourist markings. and at the same time it is understood that their number is insufficient in the mountain area taken for study. One can also notice the discrepancy between the trust granted to the county authorities with the receipt of the tourist promotion of the mountain area (see figure 2) and the tourism promotion realized by the local authorities (see figure 8). 


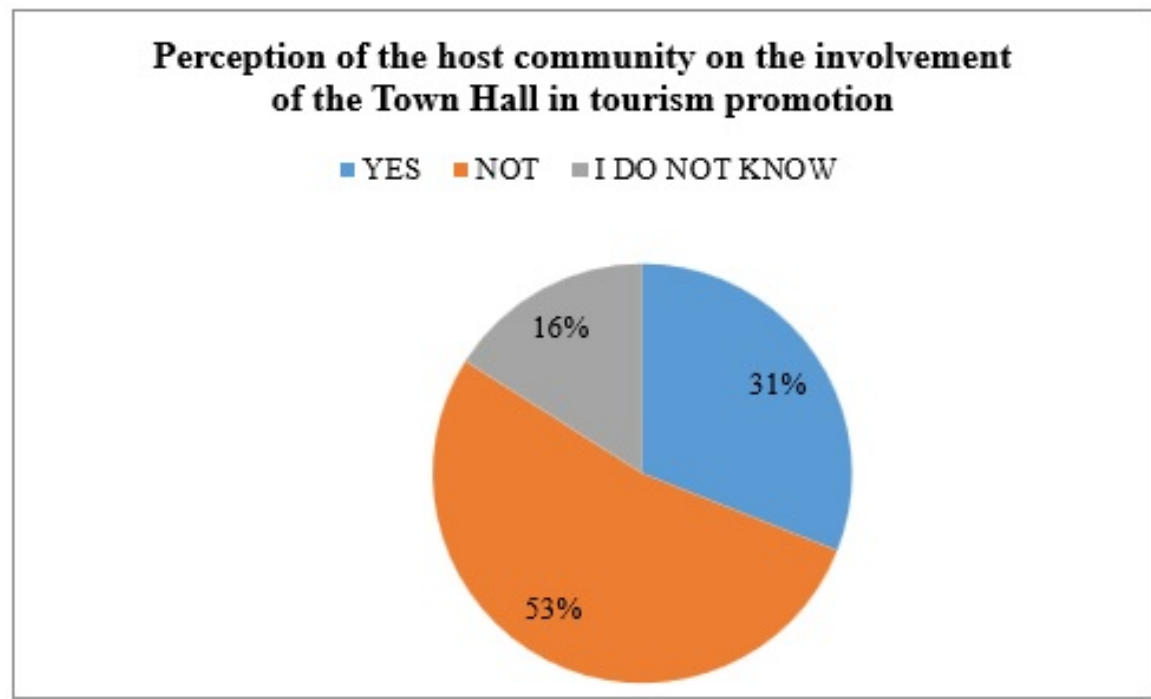

Figure 8. Distribution of answers to question no 8 .

The need for information and schooling of the host community in the studied area can be deduced from the way they handle the information. It is found that information about local development projects comes largely from neighbors and not from valid sources. To the question: From what sources do you find out mabout the development projects of your locality? Paradoxically, the fact is that a very small number find out about the local development projects on the websites of the town halls, only $3 \%$, despite the fact that Romania has a very large internet coverage and is very easy to access.

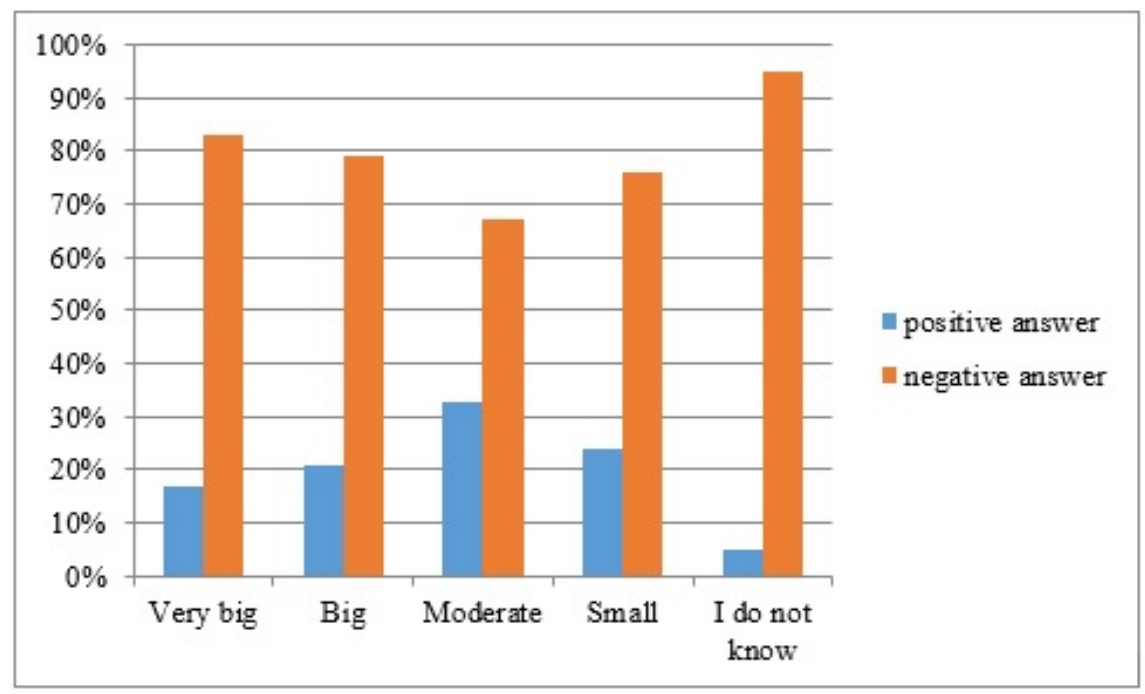

Figure 9. Distribution of answers to question no. 9.

The answers are mostly overwhelming from unofficial and invalid sources and only a small part of the respondents replied that they find out about the development projects in the public meetings of the Town Hall $4 \%$ and $4 \%$ of the Town Hall poster. (Figure 10). At the same time, we find that the host population believes that the development of tourism would contribute to the economic growth of the family. Despite the fact that the citizens are aware of the tourist resources in the mountain area of Suceava county, as well as the increase in the number of tourists, there is a reluctance to host the tourists, in their own house. It should be mentioned that in Romania, according to the legislation in force, the tourist reception structures with accommodation function that register less than 5 places are not included in the statistics [9], which is why the survey conducted is based on the sincerity of the respondents because it cannot be statistically verified. The question with number 13 refers to the interaction of tourists with the household activities. Although in European countries, rural tourism is understood as the interaction of tourists with the household [11], we find that in the studied area this aspect is present to a small extent. If you hosted tourists in your home, did they interact with the household? from the responses of the host communities, it is observed that only $21 \%$ interacted with the household, and $54 \%$ of the response was negative. (Figure 11) In 
other words, it is found that the population of the mountainous rural area needs training in order to become a good host and to learn how to use household resources to generate the interest of tourists.

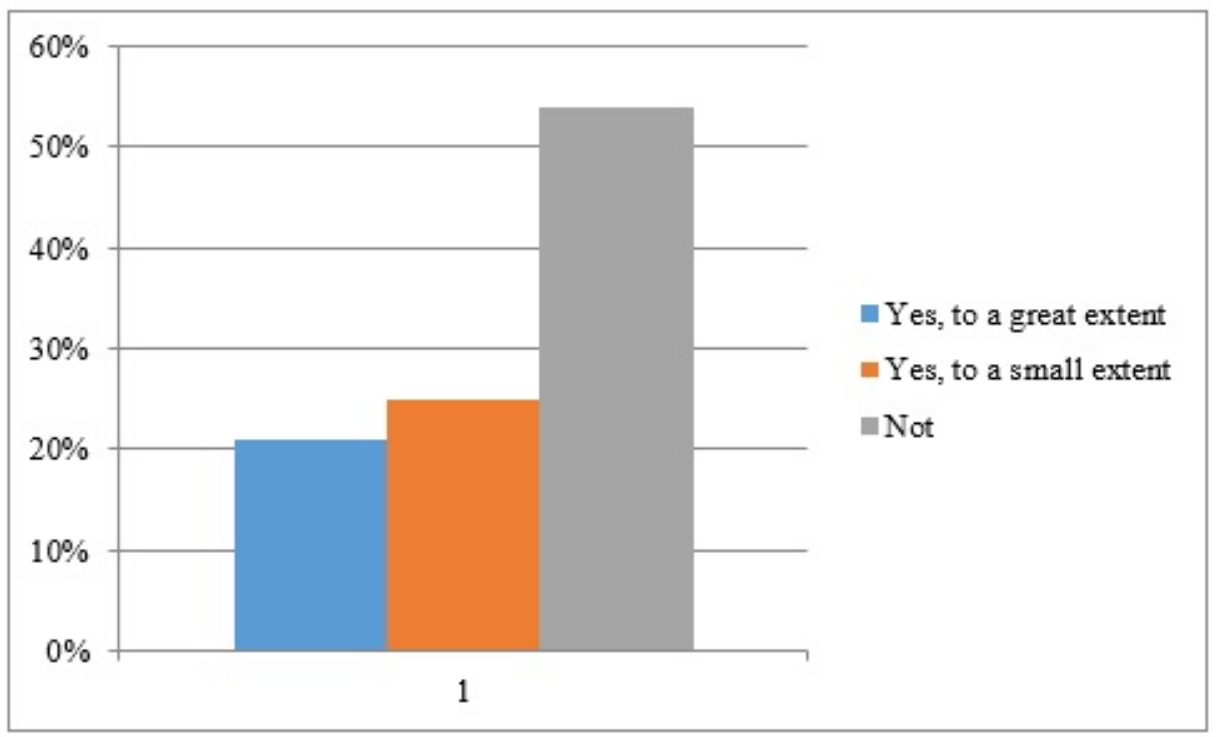

Figure 10. Distribution of answers to question no. 13.

\section{CONCLUSIONS}

Through this study we set out to find out if the mountain community is ready to be a host, if it knows the tourism development projects and what are the sources of information regarding the implementation of local projects. There is a discrepancy between what the inhabitants of the mountain communities think about the benefits of tourism development in the studied area and how they are actually involved. The host population considers $91 \%$ that the establishment of new reception structures would be beneficial to the commune, but only a small part (12\%) made it available to tourists, which shows that the potential host population is not adequately prepared to meets the requirements of tourists. Also, following the survey, it was found that the citizens of the mountain communities in Suceava believe that the European funds are to a small extent attracted by the region by the local authorities and, at the same time, the weak information of the citizens from the official sources. The possibility of a better life is the imperative solution needed in the mountain area, but the rural entrepreneurs need specialized training and support to turn them into a host who can create tourist experiences. Regarding the presence of markings and the promotion of tourism in the mountain communes, the respondents prove that their number is insufficient and that there are deficiencies in the mountain area. It is confirmed the hypothesis that the difference between the aspirations of the population in the development of rural tourism and those that are actually involved in this industry is large, and its diminution requires the training of the host population and support from the competent authorities. In conclusion, following the analysis of the results, it is found that the rural population must be trained through courses to learn how to capitalize on their existing resources and to become a good host for potential tourists. The trust of the host community in the local authorities is a weak point, but the involvement of the local authorities in the development and promotion of tourism can open new roads for the mountain village from Suceava county. In the study area, households should be assisted and help to obtain the certification of the household in order to provide tourist services. Moreover, another possibility of promotion and introduction in the tourist circuit would be the creation of a database, which could be easily accessed and thus could be encouraged rural tourism.

\section{ACKNOWLEDGMENT}

This work is supported by project POCU/380/6/13/125040, entitled "Development of the tertiary university education to support the economic growth -PROGRESSIO", co-financed by the European Social Fund under the Human Capital Operational Program 2014-2020 


\section{REFERENCES}

[1] Antonescu, D., Antonescu R. M. Sustainable development of agro-tourism in European Union and Romania, in MPRA Paper, no.56653, https://mpra.ub.uni-muenchen.de/56653/ pp 119-128, 2015.

[2] Barbu, N. Obcinele Bucovinei, Editura științifică și Enciclopedică, București, 1976, pp.20-27.

[3] Bojoi, I. et al. Suceava - Ghid turistic al județului, Editura Sport -Turism, București, 1979, pp 7-25.

[4] Brândus, C., Cristea, Al. I., -Județul Suceava- Seria Judetele României, Editura Academiei Române, București 2013, pp 86- 88.

[5] Cândea, M. Potențialul turistic al României, Editura Universitară, București, 2006, pp 15.

[6] Gogonea M., R. Posibilităţ̦i de integrare a produsului turistic rural pe piaţa turistică europeană, in Journal of Tourism, No. 3, 2007, pp. 29-35.

[7] Grigorcea, N. Turismul rural românesc și creșterea economică, in Turismul rural românesc în contextul dezvoltarii durabile. Actualitate și perspective, Editura Tehnopress, Volumul XX, Iaşi, 2010, pp 42-45.

[8] Miftode, V. Metodologia sociologică, Editura Porto-Franco, Galați, 1995, pp.250-291

[9] National Institute of Statistic. Numărul pensiunilor și pensiunilor agro-turistice din județul Suceava tempoonline/\#/pages/tables/insse-table 2018.

[10] Nistoreanu, P. Aprecieri asupra fenomenului turistic rural, in Revista de turism, No. 3, 2007, pp 16-23.

[11] Niţescu, A. Development of rural tourism in the European context, in Annals of the Constantin Brâncuşi University of Târgu Jiu, Economy Serieis, Volume II, Issue 1, 2015, pp.199-202.

[12] Rey, R. Carpații Românești la o răscruce a istoriei, Centrul de Informare și Documentare economică, București 2007, pp 1-36.

[13] Săvoiu G., et al. Mitologie românească și turism rural, in Turismul rural românesc în contextul dezvoltării durabile. Actualitate și perspective, Volumul XX, Editura Tehnopress, Iași, 2010, pp 202-212.

[14] Slusariuc, G. C., Simina A. E. Evolutions of Rural Tourism in Romania and Europe, in Economic Sciences Series, Volume XVIII, 2018 pp. 182-185.

[15] Legea muntelui no. 197/2018 